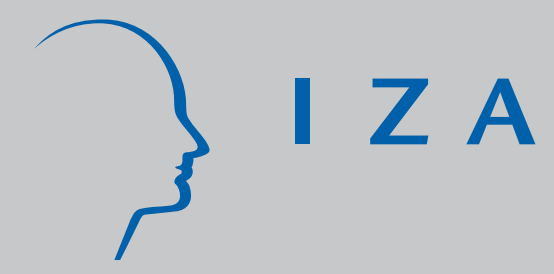

IZA DP No. 2529

The Compensating Income Variation of Social Capital

Wim Groot

Henriette Maassen van den Brink

Bernard van Praag

December 2006 


\title{
The Compensating Income Variation of Social Capital
}

\author{
Wim Groot \\ University of Maastricht \\ and SCHOLAR, University of Amsterdam \\ Henriette Maassen van den Brink \\ SCHOLAR, University of Amsterdam \\ Bernard van Praag \\ SCHOLAR, University of Amsterdam, \\ DIW Berlin, CESifo and IZA Bonn
}

\section{Discussion Paper No. 2529 \\ December 2006}

\author{
IZA \\ P.O. Box 7240 \\ 53072 Bonn \\ Germany \\ Phone: +49-228-3894-0 \\ Fax: +49-228-3894-180 \\ E-mail: iza@iza.org
}

\begin{abstract}
Any opinions expressed here are those of the author(s) and not those of the institute. Research disseminated by IZA may include views on policy, but the institute itself takes no institutional policy positions.
\end{abstract}

The Institute for the Study of Labor (IZA) in Bonn is a local and virtual international research center and a place of communication between science, politics and business. IZA is an independent nonprofit company supported by Deutsche Post World Net. The center is associated with the University of Bonn and offers a stimulating research environment through its research networks, research support, and visitors and doctoral programs. IZA engages in (i) original and internationally competitive research in all fields of labor economics, (ii) development of policy concepts, and (iii) dissemination of research results and concepts to the interested public.

IZA Discussion Papers often represent preliminary work and are circulated to encourage discussion. Citation of such a paper should account for its provisional character. A revised version may be available directly from the author. 
IZA Discussion Paper No. 2529

December 2006

\section{ABSTRACT \\ The Compensating Income Variation of Social Capital ${ }^{\star}$}

There is a small but growing literature on the determinants of social capital. Most of these studies use a measure of trust to define social capital empirically. In this paper we use three different measures of social capital: the size of the individual s social network, the extent of their social safety net and membership of unions or associations. A second contribution to the literature is that we analyze what social capital contributes to our well-being. Based on this, we calculate the compensating income variation of social capital. We find differences in social capital when we differentiate according to individual characteristics such as education, age, place of residence, household composition and health. Household income generally has a statistically significant effect. We find a significant effect of social capital on life satisfaction. Consequently, the compensating income variation of social capital is substantial.

JEL Classification: D1, D6

Keywords: life satisfaction, social capital

Corresponding author:

Bernard M.S. van Praag

Department of General Economics

University of Amsterdam

Roetersstraat 11

1018 WB Amsterdam

The Netherlands

Email: B.M.S.vanPraag@uva.nl 


\section{Introduction}

Increased individualism and higher mobility have changed the nature of family and community life. The most profound change has been the shortening of the length of relationships: a higher divorce rate has led to a shortening of the duration of marriages, higher job mobility led to a shortening of the employment relationship, the increased availability and the lowering of the costs of transportation has led to a higher geographical mobility and to a loosening of the attachment to the neighborhood.

The more individualized society has become, the more interested we have got in what people binds and holds society together, and the mechanisms that accomplish this. This has led to a re-appraisal of the value of social relations. Social capital includes all factors that foster social relations and social cohesion. In recent years a small body of literature has emerged that emphasizes the value of social capital and warns that diminished social capital leads to an erosion of social cohesion (see Bourdieu 1986, Arrow 1999, Putnam 1995, 2000, Fukuyama 1995, 1999, Helliwell \& Putnam 1999, Solow 1999 and Woolcock 2000. For a critical discussion of the concept of social capital, see Durlauf 1999, 2002, Durlauf \& Fafchamps 2004 and Sobel 2000).

In this paper we contribute to the literature on social capital by analyzing the determinants and the value of three aspects of social capital: the size of the social network (how many people you interact with in your neighborhood), the extent of the social safety net (i.e. the extent to which one can call on others when necessary), and the membership of unions and associations. 
Social capital is supposed to have an important economic value. The World Bank argues that: "Increasing evidence shows that social cohesion is critical for societies to prosper economically and for development to be sustainable. Social capital is not just the sum of the institutions which underpin a society - it is the glue that holds them together" (http://www.worldbank.org/poverty/scapital/).

In many studies social capital is operationalized as the extent to which people trust their fellow men (see Glaeser et. al 1999, 2000, 2000a, Alesina \& La Ferrara 2000, Knack \& Keefer 1997, La Porta et. al 1997). Most of these studies find that trust is related to education: higher educated people are more likely to put trust in others than lower educated people. People with higher educated parents are also more likely to be trustful. Further, men, people who are married and people with a strong religious conviction are more likely to trust other people. Alesina \& La Ferrara (2000) find that the most important factors that lead to having less trust in others are: traumatic experiences in the past, belonging to a group that believes they have been discriminated (blacks, women), being economically not successful, and living in a neighborhood with people from different ethnic origins and/or with large income differences.

A second way in which social capital is operationalized in the literature is by membership of clubs or groups such as unions, church, sports clubs, reading clubs, etc.. Glaeser et. al. (2000b) find a positive relation between education and membership of an association. They conclude from this that human capital and social capital are complements. This study further finds that membership of an association is inverse U-shaped in age (like investments in human capital), and that a higher geographical mobility reduces the probability of membership of an association. Workers in occupations that require social skills are more likely to join a club. The 
probability to be a member of a club is also higher if one is a house-owner and if the commuting time to work is shorter.

Our paper differs from previous studies on social capital in two respects. First, we use a different measure of social capital. Previous studies have mainly used a question on trust in other people to operationalize social capital. In this paper we define social capital by the size of the social network (i.e. the number of households in the neighborhood with whom one has contacts), the extent of the social safety net (i.e. the extent to which one can call upon people when necessary) and membership of unions or associations. We analyze what determines these aspects of social capital.

After we have operationally defined social capital and we have analyzed the determinants of our three social capital indicators, the main question we address is how social capital contributes to individual well-being or happiness? We use the outcome of the analyses of the effects of our three social capital indicators on life satisfaction to estimate the monetary equivalent of the benefits of social capital. The social capital effects on life satisfaction are used to calculate the compensating income variation of the three dimensions of social capital distinguished, i.e. the amount of money that compensates for a change in each of the three dimensions of social capital while keeping the level of well-being constant.

Well-being or life satisfaction is measured by the response to the so-called Cantril scale. This measures life satisfaction on a 0 to 10 scale: steps on the so-called ladder of life. This measure of life satisfaction is also referred to in the literature as the SelfAnchoring Striving Scale (SASS). The Cantril scale has been shown to have 
adequate reliability and validity (see Beckie \& Hayduk 1997 and Mclntosh 2001). According to Diener \& Suh (1999, p. 437), 'When self-reports of well-being are correlated with other methods of measurement, they show adequate convergent validity.' Diener \& Suh (1997) assert that the major advantage of the subjective wellbeing measures is '(...) That they capture experiences that are important to the individual' (p. 205). As a major disadvantage they note that 'although self-reported measures of well-being have adequate validity and reliability, it is naive to assume that every individual's responses are totally valid and accurate' (p. 206). Their review further shows that there is a high correlation between life satisfaction and a social index that includes cost of living, ecology, health, culture and entertainment, freedom and infrastructure indicators. Diener \& Shuh $(1997,1999)$ further assert that life satisfaction measures are found to be stable over time and across countries. ${ }^{1}$

Measures of subjective well-being - such as the Cantril scale - are widely used in psychology and social sciences, but not so much in economics. There are some notable exceptions, however (see, for example Groot \& Maassen van den Brink 2003, 2004, Van Praag, Frijters \& Ferrer-I-Carbonell 2003, Van Praag \& Ferrer-ICarbonell 2002).

Diener \& Shuh (1999) report that the average Pearson correlation between mean levels of subjective well-being reported for nations in three different international surveys is 0.71 . An overview of average levels of well-being in forty-one nations shows that average life satisfaction in 1994 ranged from 5.03 in Bulgaria to 8.39 in Switzerland (Diener \& Shuh 1999, p. 436). 


\section{The empirical model}

The starting point of the empirical model is the life satisfaction or happiness function $\left(U^{*}\right)$. It is assumed that life satisfaction is determined by income $Y$, social capital SC and other individual characteristics $\mathrm{X}$ :

$$
U^{*}=U^{*}(Y, S C, X)
$$

where $\mathrm{Y}$ is the net (monthly) household income. We distinguish three aspects of social capital: the size of the social network (SC1), the extent to which one can call on others when necessary (SC2), and membership of a union of association (SC3). We assume the following relationship between social capital and life satisfaction:

$$
U^{*}=\beta_{0}+\beta_{y} \log (Y)+\beta_{1} S C 1+\beta_{2} S C 2+\beta_{3} S C 3+\beta_{X} X+\varepsilon
$$

where $\beta$ are coefficients that measure the impact of income, social capital and other characteristics on life satisfaction, and $\varepsilon$ is a normally distributed random error term capturing unmeasured and unmeasurable effects on life-satisfaction. The Log of income is used instead of income itself following other authors (see e.g. Diener 1984, Veenhoven 1996 and Groot \& Maassen van den Brink 2000).

Quality of life or life satisfaction is a latent variable that is not directly observable. What we observe is the response to a question on life-satisfaction in general. We dispose in our data set of the observed level of life-satisfaction $U^{\circ}$ as a categorically 
ordered response variable. Response classes are ordered $0, \ldots, 10$. The observed lifesatisfaction variable is assumed to be related to the latent happiness variable in the following way:

$$
U^{o}=i \text { if } \quad \alpha_{i-1}<U^{*} \leq \alpha_{i} \quad i=1, \ldots, n
$$

where $n$ is the number of response categories and $\alpha_{i}$ are threshold levels. This equation states that if happiness $U^{*}$ is between $\alpha_{i-1}$ and $\alpha_{i}$, the response to the question of life satisfaction is equal to $\mathrm{i}\left(\mathrm{U}^{\circ}=\mathrm{i}\right)$. We assume that the lower bound of the observed life-satisfaction variable corresponds with the lowest possible level of happiness, while the upper bound of the observed life-satisfaction variable corresponds to the highest possible happiness level that can be attained. This amounts to the assumption that life-satisfaction can range from $-\infty$ (minus infinity) to $\infty$ (infinity). We therefore set $\alpha_{0}=-\infty$ and $\alpha_{n}=\infty$. The remaining $n-1$ threshold levels are estimated. This is the specification of the well-known ordered Probit-model (McKelvey \& Zavoina 1975).

The parameter estimates are used to calculate the compensating income variation of social capital, i.e. the income increase needed to make someone with limited social capital as well off as someone with more social capital. Let $\mathrm{C}\left(\mathrm{X} ; \mathrm{U}, \mathrm{SC}_{\mathrm{i1}}\right)$ represent the income necessary for an individual with social capital level $\mathbf{S C}_{\mathrm{i} 1}$ and characteristics $\mathrm{X}$ to attain life satisfaction level $\mathrm{U}$, and let $\mathrm{C}\left(\mathrm{X} ; \mathrm{U}, \mathrm{SC}_{\mathrm{i}}\right)$ represent the income necessary for an individual with the same characteristics $X$ with social capital $\mathrm{SC}_{\mathrm{i} 0}$ to attain the same level of life satisfaction (i refers to the three indicators of 
social capital, i.e. $i=1,2,3)$. The equivalence scale of social capital ES is then defined as:

$$
E S=\frac{C\left(X ; U, S C_{i l}\right)}{C\left(X ; U, S C_{i 0}\right)}
$$

Taking logs and substituting the expression for the cost function derived from the life satisfaction function, we obtain:

$$
\begin{gathered}
\log E S=\log C\left(X ; U, S C_{1}\right)-\log C\left(X ; U, S C_{0}\right)= \\
\frac{\beta_{i}}{\beta_{y}} \Delta S C
\end{gathered}
$$

where $\Delta \mathrm{SC}=\mathrm{SC}_{\mathrm{i} 1}-\mathrm{SC}_{\mathrm{i} 0}$.

In order to assess the monetary value of the size of the social network and the extent of the social safety net, we calculate the ES of one higher point score on the aspects of social capital - i.e. $\mathrm{SC}_{\mathrm{i} 1}=\mathrm{SC}_{\mathrm{i} 0}+1$ - for each individual in our sample separately. For membership of an association, we compare between being a member and not being a member. Next, we calculate the aggregate compensating income variation (CV) of social capital by multiplying the ES by the average monthly household income of the individuals in our sample. 


\section{Data and descriptive analysis}

The data for the empirical analysis are taken from the GPD-survey 2002. This data set is collected in a somewhat unorthodox way as a survey in Dutch dailies. The response on this anonymous survey without reminders, etc. is relatively low at about $2 \%$, but, since the total readership exceeds two million subscribers, the absolute number of about 40,000 is extremely high. Similar surveys have been carried out in $1983,{ }^{\prime} 84, ' 91, ' 98$. The experiences with this survey are very good. We notice that the survey is not completely representative for the Dutch population, as ethnic minorities and non-readers of daily news are hardly represented. For the core of the Dutch population the surveys appear to be representative after usual reweighting. But, we should keep in mind that for our objectives representativity is relatively less important, as we try to estimate relationships in the first place. It is obvious that in order to assess aggregate numbers over the population we have to reweigh as best as possible.

We use three indicators of social capital. The first is the size of the social network (SC1). The size of the social network is determined by the response to the following survey question: "With how many households or families in your neighborhood do you associate with?". The second indicator is the extent of the social safety net people have (SC2). The extent of the social safety net is determined by the response to the question: "Are there people you can fall back on when you are ill or you have problems? Can you fall back on: a) neighbors, b) children, c) family members, d) friends and e) others." For each of these five categories of people respondents can 
indicate whether they could fall back on them 1=never, 2=with some effort, $3=$ possible, $4=$ =always.

Finally, we use the question "Are you a member of a trade union or special interest group (consumer organization, association of home owners, etc.)?" (SC3) as an indicator of social capital, where 0 stands for 'no' and 1 for 'yes'.

Table 1 contains the frequency distribution of the number of households in the neighborhood with whom one has contacts. A little over a third of the respondents has contacts with one or two households in the neighborhood, while a little less than a third has contacts with 5 households or more. On average people have contacts with 3.3 households in the neighborhood. There is little difference in the frequency distribution of the size of the social network in the neighborhood between men and women in our sample.

The questions about the social safety net refer to the extent to which one can call upon children, family, friends or others when necessary. Respondents are asked to indicate for all four of these on a scale from 1 (never) to 4 (always) whether one can call on them. The sum score of the answers to these questions is used in the analyses. The sum score of the social safety net runs from 5 for respondents who indicated 'never' on all questions to 20 for people who can always rely on all of the four groups distinguished.

Table 2 has the frequency distribution of the social safety net scale. Only $0.6 \%$ of all respondents say 'never' to all five items in the scale, while only $3.8 \%$ respond 'always' to all items. The average score on the social safety net scale is 14.2. Converted to the four point scale, this most closely corresponds to 'possible' on the 
scale from 'never' to 'always' on the social safety net. Again we find little difference in the frequency distribution and the average score on the social safety net scale between men and women.

The third indicator of social capital is a dummy variable that equals one if the respondent is a member of at least one trade union or special interest association and equals zero otherwise. Table 3 contains the frequency distribution of the membership variable. About $43 \%$ of the respondents is member of a union or special interest group. Here we do find a difference between men and women: men are more likely to be a member than women. More than $48 \%$ of the men is member of a union or interest group. Among women $36.5 \%$ has joined a union or interest group.

The three indicators of social capital are included in the life satisfaction equation. The level of life satisfaction is measured by the so-called Cantril (1965) scale. The life satisfaction question is phrased as follows: 'Here is a picture of a ladder, representing the ladder of life. The bottom of this ladder, step 0 , represents the worst possible life, while the top of this ladder, step 10, represents the best possible life. Where on this ladder do you feel you personally stand at present?'

Table 4 contains the frequency distribution of life satisfaction. About $4 \%$ of the respondents rate their life 5 or less. A similar number of people (3.6\%) give their life the highest possible value, a 10 . Most people rate their life at 7 or 8 . The average rating of life satisfaction is 7.6. The average rating is almost identical for men and women. 


\section{The determinants of social participation}

Table 5 contains the estimation results of a OLS regression on the log-size of the social network. The OLS estimates on the log-extent of one's social safety net and the probit estimates on membership of a trade union or association are found in table 6 and 7 , respectively.

There are no statistically significant differences between men and women in the size of the social network and the extent of the social safety net. The only difference we find is for membership of a union or association: men are more likely to be a member than women. This difference may be due to differences in the labor force participation rate of men and women: men are more likely to participate in the labor market and are - partly because of this - more frequently member of a trade union.

Having a paid job is negatively associated with the (log of the) size of the social network and positively with log of the social safety net scale and the probability of being a member of a union or association. Only among men, having a paid job does not have a statistically significant effect on the size of the social network. Among women the point estimates indicate that being employed reduces the size of the social network by nearly $11 \%$. The explanation for this finding is that people with a paid job probably have less time to invest in relations with people in their neighborhood.

A paid job increases the social safety net scale of men (2.3\%) a little less than the social safety net scale of women (3.6\%). This effect probably is partly caused by the fact that elderly retired people have fewer friends and family members on whom 
they can call when necessary. This finding also suggests that people who are successful in finding a paid job (or employment protection) are also more skillful in creating a social safety net for themselves.

Higher educated people have a larger social network and are more likely to be member of a union or interest group. This finding suggests that human capital (education) and social capital are complements. This confirms earlier findings that show that human capital and trust in other people are complements (see Glaeser et. al. 2000b).

A year of education increases the social network by $0.6 \%-0.8 \%$. Education does not have a statistical significant effect on the extent of the social safety net of men. Among women a year of education appears to reduce the social safety net scale by $0.6 \%$.

Both age variables have a statistically insignificant effect on the size of the social network. However, if we only include log age (and exclude log age squared) we find that age has a positive and statistically significant effect on the log of the social network.

Age has an inverse $\mathrm{U}$-shaped effect on the log of the social safety net scale. The top of the age parabola is around age 50 , i.e. until that age the log of the social safety net scale increases in age, while after that it starts to decline. The extent of the social safety net declines as people get older. Elderly people may become more socially isolated, partly because relatives and friends are deceased or are elderly themselves as well and less able to lend social support. It might be expected that the need for a social safety net increases with age, as people become more dependent 
on others when they are old. So, the extent of the social safety net decreases when the need for one increases.

Older people are more likely to be a member of a union or interest group. We find a statistically significant and positive effect of the variable 'log age' for men and of 'log age squared' for women.

People living in a large city have a smaller social network than those living in a small city (or municipality) or at the country side. This can be seen as indicative for the greater anonymity and individualism of living in a large city.

There are no statistically significant differences in the size of the social network between people in a small village and people in a middle sized municipality. The point estimates indicate that there is a $7 \%$ difference in the size of the social network between people in a large city and people living in a small village. We also find that people living in a municipality have a smaller social safety net. Living in a middle sized municipality reduces the social safety net scale by $1.5 \%$ compared to people living in a small village.

Both the sizes of the social network and the social safety net increase with the number of years people have lived in the same house. A longer stay in the same house and neighborhood not only increases the opportunities to build a social network and a social safety net of people living in the same neighborhood, but a lower residential mobility also makes it more attractive to invest in building this kind of social relations. Each year living in the same house increases the size of the social network and the social safety net scale by $0.1 \%$. 
People who are married or who live together ${ }^{1}$ with a partner have more social capital: being married or living together increases the size of the social network and the extent of the social safety net. Characteristics that make one more successful on the marriage or partner market apparently also increase one's social capital.

There are some notable differences between men and women in the effect of marital status on the social network and the social safety net. For men the effect on the size of the social network of being married is much smaller than for women. For men being married increases the size of the social safety net by $3.9 \%$, for women this is $6.7 \%$. The reverse holds for the effect of being married on the social safety net scale. Here the effect on men is larger than for women. Among men being married increases the social safety net scale by $7.9 \%$, while among women this is only $2.6 \%$. It seems to indicate that superficial social relations are triggered by the male partner and that the intensive relations, yielding a social safety net, depend on the female partner. Being married or living together does not have a statistically significant effect on being a member of a union or special interest group.

The effects of children on social capital is mixed. The presence of young children is associated with a larger social network but a lower social safety net scale. The presence of older children is associated with a smaller social network but a higher score on the social safety net scale. Children have no statistically significant effect on membership of a union or special interest group.

Household income does not have a statistically significant effect on the size of the social network, nor on the social safety net scale. Household income does have a

\footnotetext{
1 In this study we do not differentiate between the formal marriage status and steady partnership without being formally married.
} 
statistically significant and positive effect, however, on the probability of membership of a union or special interest group.

Being a member of an ethnic minority is associated with a lower extent of the social safety net. Among men, ethnic minority members are less likely to be a member of a union or special interest group. The ethnic minority variables do not have a statistically significant effect on the size of the social network.

Having conservative political opinions (i.e. people who intend to vote for one of the parties belonging to the right side of the political spectre) is associated with a larger social network. Men with conservative political opinions also have a higher score on the social safety net scale. Among women, conservative political opinions do not have a statistically significant effect on the social safety net scale. People with conservative opinions are further less likely to be a member of a trade union or association. This is not surprising as conservative individuals are not inclined to join a union or association to change the present situation. Conservatives may be expected to be more likely to be satisfied with the current situation.

Finally we find that a good health increases the size of the social network and is associated with a higher score on the social safety net scale, but lowers the probability that one is a member of a trade union or association. A better health probably enables one to invest in social contacts in the neighborhood and in a social safety net, and a healthy person is more attractive for other persons to associate with. Apparently, a better health reduces the need for protection by a union or special interest group. 


\section{The effects of social participation on life satisfaction}

Table 8 contains the parameter estimates of the ordered probit regressions on life satisfaction. Again, we present estimates for the joint sample and for men and women separately. In the estimates for the entire population we find a statistically significant negative effect of gender indicating that men are less satisfied with their life than women.

With respect to our three indicators of social capital we find for both men and women positive and statistically significant effects of the log-size of the social network and of the log of the social safety net scale. That is, men and women who have a larger social network or whose social safety net is more extensive are more satisfied with their life. Membership of a union or association does not have a statistically significant effect on life satisfaction.

We now briefly discuss the other findings. If we control for education and income, having a paid job does not have a statistically significant effect on life satisfaction. This finding holds for both men and women.

For men life satisfaction increases with education and the log of age. For women both education and age do not have a statistically significant effect on life satisfaction.

Being married or living together with a partner increases life satisfaction for both men and women. The effects of the presence of children on life satisfaction is mixed. For men, the presence of children in the age 4 to 12 years old lowers life 
satisfaction. For women, having children aged 18 or older increases life satisfaction. Children in other age categories have a statistically non-significant effect on life satisfaction.

Men with conservative political opinions have a higher life satisfaction. This can be expected as people with conservative opinions are satisfied with the 'status quo', while people who consider themselves to be 'progressive' want change and are less satisfied with the current situation.

Finally, we find that both for men and women life satisfaction strongly increases with the quality of health.

\section{The compensating income variation of social capital}

Table 9 contains the equivalence scales (ES) and compensating income variations (CV) of social capital. For the entire population in our sample the ES of the size of the social network is 1.162. For women the ES of social network is somewhat larger than for men, indicating that women attach a higher value to a social network than men do.

The CV of social capital is calculated by multiplying the equivalence scale by the average net household income per month of the respondents in our sample (Euro 2710). The CV of a one unit increase in the size of the social network is Euro 438 per month. At the average level of household income the CV is 415 Euro for men and 570 Euro for women.

The ES of the social safety net scale is 1.328 . Again we find a larger ES for women than for men. For women the ES is 1.434 while it is 1.290 for men. At the 
average level of household income this corresponds to a CV of a unit change on the social safety net scale of 787 Euro for men and 1176 Euro for women.

The ES of membership of a union or association is 0.982 . For a respondent with an average monthly income this corresponds to a cost of membership of 50 Euro per month. It should be kept in mind, however, that none of the coefficients of membership of a union or association is statistically different from zero. Further, the decision for membership is endogenous and it is quite probable that for nonmembers the value of membership is much less than for members and consequently they have chosen for non-membership.

\section{Conclusion}

Most empirical studies have used a measure of trust or membership of clubs or organizations to measure social capital. In this paper we have used some different measures: the size of the social network, the extent of the social safety net, and membership of a union or association. Our findings on the determinants of social capital in some respects confirm those of earlier studies. Other findings cannot be replicated using our definition of social capital. Earlier studies for example found that gender, ethnic origin and economic success have an effect on trust in one's fellow men. In our study we do not find statistically significant effects of gender, ethnic origin or household income on the size of the social network or the extent of the social safety net. Other results, however, are confirmed by our findings. Like in previous studies we find that a higher education and being married or cohabiting is positively associated with social capital. 
A second objective of this paper was to quantify the effect of social capital as defined above on life satisfaction. Does more social capital make people more satisfied with their life? We find that there is a significant correlation between social capital and life satisfaction. Reluctantly we assume a causality relationship, where having social capital increases life satisfaction, although the link may also be interpreted inversely. As individuals are more satisfied with life, they will be nicer company for others and consequently have more friends and relations. However, there is no doubt that social capital affects life satisfaction quite considerably. This is illustrated by the compensating income variation of the three measures of social capital.

The compensating variation of social capital in terms of money is sizeable. This suggests that people attach a high value to social capital indicators as the size of their social network and the extent of their social safety net.

In this paper we analyzed the effect of social capital in various forms on life satisfaction. Although we are fully aware that there are many facets of social capital that we have not adequately covered by the three indicators at our disposal, we have found unmistakable indications for the importance of social capital for life. 


\section{References}

Alesina, A. \& W. La Ferrara (2000), 'The determinants of trust', NBER Working Paper 7621

Arrow, K. (1999), 'Observations on social capital', in: P. Dasgupta \& I. Serageldin (eds.), Social Capital: A Multifaceted Perspective, Washington, The Worldbank, p. 35

Beckie, T. \& L. Hayduk (1997), 'Measuring quality of life', Social Indicators Research 42, p. 21-39

Bourdieu, P. (1986), 'Forms of capital', in: J. Richardson (ed.), Handbook of Theory and Research for the Sociology of Education, Greenwood Press, Westport, p. 241260

Diener, E. (1984), 'Subjective well-being', Psychological Bulletin 95, p. 542-575

Diener, E. \& E. Suh (1997), 'Measuring quality of life: economic, social, and subjective indicators', Social Indicators Research 40, p. 189-216

Diener, E. \& E. Shuh (1999), 'National differences in subjective well-being', in: D. Kahneman \& N. Schwarz (eds.), Well-being: The Foundations of Hedonic Psychology, Russell Sage Foundation, New York, p. 434-450

Durlauf, S. (1999), 'the case against social capital', Focus 20, p. 1-4

Durlauf, S. (2002), 'Bowling alone: a review essay', Journal of Economic Behavior and Organization 47, p. 259-273

Durlauf, S. \& M. Fafchamps (2004), 'Social Capital', Working Paper, NBER working paper 10485

Fukuyama, F. (1995), Trust, Free Press, New York

Fukuyama, F. (1999), The Great Disruption: Human Nature And The Reconstitution of Social Order, Profile Books, London

Glaeser, E., D. Laibson, J. Scheinkman \& C. Soutter (1999), 'What is social capital? The determinants of trust and antitrust', NBER Working Paper 7216

Glaeser, E., D. Laibson, J. Scheinkman \& C. Soutter (2000a), 'Measuring trust', Quarterly Journal of Economics 115, p. 811-846

Glaeser, E., D. Laibson \& B. Sacerdote (2000b), 'The economic approach to social capital', NBER Working Paper 7728

Groot, W. \& H. Maassen van den Brink (2000), 'Life-satisfaction and preference drift', Social Indicators Research 50, p. 315-328 
Groot, W. \& H. Maassen van den Brink (2003), 'Sympathy and the value of health: the spill-over effects of migraine on household well-being', Social Indicators Research 61, p. 97-120

Groot, W. \& H. Maassen van den Brink (2004), 'A direct method for estimating the compensating income variation for severe headache and migraine', Social Science and Medicine 58, p. 305-314

Helliwell, J. \& R. Putnam (1999), 'Education and social capital', NBER Working Paper 7121

Knack, S. \& P. Keefer (1997), 'Does social capital have an economic payoff? A cross-country investigation', Quarterly Journal of Economics 112, p. 1251-1288

McIntosh, C. (2001), 'Report on the construct validity of the temporal satisfaction with life scale', Social Indicators Research 54, p. 37-61

McKelvey, R. \& W. Zavoina (1975), 'A statistical model for the analysis of ordinal level dependent variables', Journal of Mathematical Sociology 4, p. 103-120

Putnam, R. (1995), 'The case of missing social capital', mimeo

Putnam, R. (2000), Bowling Alone: The Collapse and Revival of American Community, Simon \& Schuster, New York

Sobel, J. (2002), 'Can we trust social capital', Journal of Economic Literature 40, p. 139-154

Solow, R. (1999), 'Notes on social capital and economic performance', in: P. Dasgupta \& I. Serageldin (eds.), Social Capital: A Multifaceted Perspective, Washington, The Worldbank, p. 6-10

Van Praag, B. \& A. Ferrer-I-Carbonell (2002), 'The subjective costs of health losses due to chronic diseases: an alternative model for monetary appraisal', Health Economics 11, p. 709-722

Van Praag, B., P. Frijters \& A. Ferrer-I-Carbonell (2003), 'The anatomy of subjective well-being', Journal of Economics Behavior and Organization 51, p. 29-49

Veenhoven, R. (1996), 'Developments in satisfaction research', Social Indicators Research 37, p. 1-46

Woolcock, M. (2000), 'The place of social capital in understanding social and economic outcomes', The World Bank 


\begin{tabular}{|c|c|c|c|c|c|c|}
\hline \multicolumn{7}{|c|}{$\begin{array}{l}\text { Table } 1 \text { Frequency distribution social network: "with how many households } \\
\text { or families in your neighbourhood do you associate with?" (number of } \\
\text { observations in brackets) }\end{array}$} \\
\hline & 1 & 2 & 3 & 4 & 5 or more & Mean \\
\hline All & 11.93 & 22.92 & 18.68 & 14.98 & 31.48 & $\begin{array}{l}3.31 \\
(N=13209)\end{array}$ \\
\hline Men & 11.12 & 22.54 & 18.4 & 15.09 & 32.85 & $\begin{array}{l}3.36 \\
(N=7808)\end{array}$ \\
\hline Women & 13.43 & 23.64 & 19.21 & 14.77 & 28.95 & $\begin{array}{l}3.22 \\
(N=4280)\end{array}$ \\
\hline
\end{tabular}




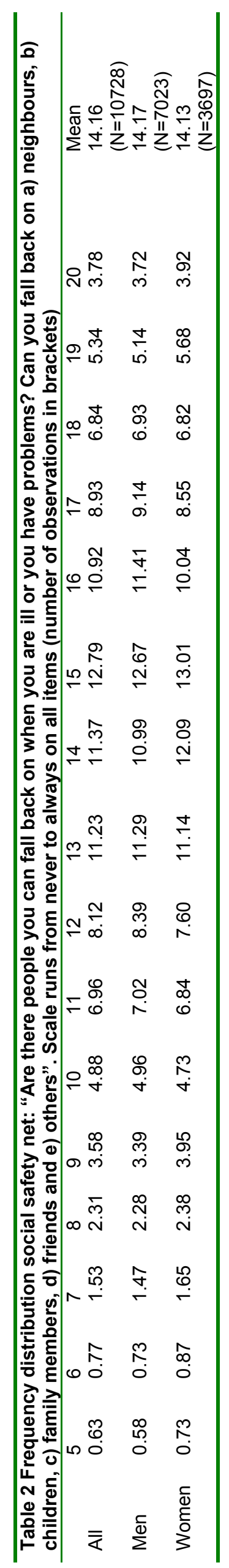




\begin{tabular}{|c|c|c|c|}
\hline & $\begin{array}{l}\text { Respondent is } \\
\text { member }\end{array}$ & $\begin{array}{l}\text { Respondent is not } \\
\text { a member }\end{array}$ & Mean \\
\hline All & 43.99 & 56.01 & $0.439(\mathrm{~N}=14584)$ \\
\hline Men & 48.23 & 51.77 & $0.482(\mathrm{~N}=9340)$ \\
\hline Women & 36.51 & 63.49 & $0.365(\mathrm{~N}=5232)$ \\
\hline
\end{tabular}

\begin{tabular}{llllllllllll}
\hline \multicolumn{10}{l}{$\begin{array}{l}\text { Table 4 Frequency distribution cantril scale (number of observations in } \\
\text { brackets) }\end{array}$} \\
\hline \multirow{2}{*}{ All } & 1 & 2 & 3 & 4 & 5 & 6 & 7 & 8 & 9 & 10 & Mean \\
& 0.1 & 0.2 & 0.4 & 1.0 & 2.2 & 6.7 & 27.5 & 46.6 & 11.5 & 3.6 & 7.63 \\
& 5 & 0 & 0 & 2 & 3 & 1 & 1 & 2 & 3 & 2 & $(\mathrm{~N}=14458$ \\
Men & 0.1 & 0.1 & 0.4 & 0.9 & 2.0 & 6.1 & 27.1 & 47.8 & 11.4 & 3.7 & 7.65 \\
& 8 & 5 & 1 & 9 & 2 & 4 & 6 & 2 & 1 & 2 & $(\mathrm{~N}=9254)$ \\
wome & 0.0 & 0.2 & 0.3 & 1.0 & 2.5 & 7.7 & 28.1 & 44.5 & 11.7 & 3.4 & 7.59 \\
$\mathrm{n}$ & 8 & 9 & 9 & 8 & 8 & 2 & 8 & 1 & 3 & 5 & $(\mathrm{~N}=5192)$ \\
\hline
\end{tabular}

\begin{tabular}{|c|c|c|c|}
\hline \multicolumn{4}{|c|}{$\begin{array}{l}\text { Table } 5 \text { Parameter estimations OLS model log social network (standard errors } \\
\text { in brackets) }\end{array}$} \\
\hline & All & Men & Women \\
\hline Gender & $0.018(0.011)$ & & \\
\hline Employed & $-0.055^{\star *}(0.014)$ & $-0.015(0.018)$ & $-0.108^{* *}(0.021)$ \\
\hline Years of education & $0.006^{* *}(0.002)$ & $0.006^{*}(0.002)$ & $0.008^{*}(0.004)$ \\
\hline Log Age squared & $0.037(0.037)$ & $0.045(0.042)$ & $0.095(0.090)$ \\
\hline Log Age & $-0.183(0.280)$ & $-0.223(0.311)$ & $-0.609(0.670)$ \\
\hline City & $-0.074^{* *}(0.012)$ & $-0.074^{* *}(0.015)$ & $-0.070^{* \star}(0.020)$ \\
\hline Municipality & $-0.008(0.004)$ & $-0.005(0.005)$ & $-0.014(0.007)$ \\
\hline Years in house & $0.001^{* *}(0.000)$ & $0.001 *(0.001)$ & $0.001(0.001)$ \\
\hline Living together & $0.051^{* *}(0.014)$ & $0.039 *(0.019)$ & $0.067^{* \star}(0.021)$ \\
\hline Child aged $<4$ & $0.126^{* *}(0.019)$ & $0.138^{* *}(0.024)$ & $0.106^{* *}(0.030)$ \\
\hline Child aged 4 - 12 & $0.002(0.017)$ & $0.005(0.022)$ & $-0.003(0.028)$ \\
\hline Child aged $12-18$ & $-0.026(0.019)$ & $-0.036(0.024)$ & $-0.011(0.031)$ \\
\hline Child aged $>18$ & $-0.078^{* *}(0.017)$ & $-0.059^{* *}(0.022)$ & $-0.106^{* *}(0.027)$ \\
\hline Log household income & $0.001(0.008)$ & $-0.005(0.010)$ & $0.010(0.014)$ \\
\hline Ethnic minority & $-0.002(0.028)$ & $-0.003(0.036)$ & $0.000(0.045)$ \\
\hline Conservative & $0.042^{* \star}(0.010)$ & $0.043^{* *}(0.012)$ & $0.041^{*}(0.017)$ \\
\hline Health & $0.015^{\star *}(0.005)$ & $0.007(0.006)$ & $0.027^{* *}(0.008)$ \\
\hline Intercept & $1.535^{\star *}(0.525)$ & $1.632^{\star \star}(0.590)$ & $2.223(1.239)$ \\
\hline Adjusted $\mathrm{R}^{2}$ & 0.036 & 0.026 & 0.053 \\
\hline
\end{tabular}




\begin{tabular}{|c|c|c|c|}
\hline Number of observations & 9480 & 6205 & 3275 \\
\hline \multicolumn{4}{|c|}{$\begin{array}{l}\text { Table } 6 \text { Parameter estimations Log social safety net (standard errors in } \\
\text { brackets) }\end{array}$} \\
\hline & All & Men & Women \\
\hline Gender & $-0.006(0.006)$ & & \\
\hline Employed & $0.027^{* *}(0.007)$ & $0.023^{* *}(0.010)$ & $0.036^{* *}(0.012)$ \\
\hline Years of education & $-0.001(0.001)$ & $0.001(0.001)$ & $-0.006 * *(0.002)$ \\
\hline Log age squared & $-0.028^{*}(0.014)$ & $-0.068^{* *}(0.023)$ & $-0.017(0.018)$ \\
\hline Log age & $0.216 *(0.101)$ & $0.529 * *(0.169)$ & $0.103(0.128)$ \\
\hline City & $-0.005(0.007)$ & $-0.018^{*}(0.008)$ & $0.017(0.012)$ \\
\hline Municipality & $-0.014^{* *}(0.002)$ & $-0.015^{* *}(0.003)$ & $-0.013^{* *}(0.004)$ \\
\hline Years in house & $0.001^{* *}(0.000)$ & $0.001^{* *}(0.000)$ & $0.002^{* *}(0.001)$ \\
\hline Living together & $0.059 * *(0.008)$ & $0.079 * *(0.010)$ & $0.026 *(0.012)$ \\
\hline Child aged < 4 & $-0.024 *(0.011)$ & $-0.044^{* *}(0.014)$ & $0.007(0.018)$ \\
\hline Child aged $4-12$ & $0.057^{* *}(0.010)$ & $0.052^{* *}(0.012)$ & $0.064^{* *}(0.016)$ \\
\hline Child aged $12-18$ & $0.083^{* *}(0.011)$ & $0.073^{* *}(0.014)$ & $0.103^{* *}(0.018)$ \\
\hline Child aged $>18$ & $0.008(0.010)$ & $0.006(0.012)$ & $0.014(0.016)$ \\
\hline Log household income & $-0.001(0.005)$ & $-0.008(0.006)$ & $0.011(0.008)$ \\
\hline Ethnic minority & $-0.034^{*}(0.016)$ & $0.004(0.020)$ & $-0.091^{* *}(0.026)$ \\
\hline Conservative & $0.017^{* *}(0.006)$ & $0.026^{* *}(0.007)$ & $-0.002(0.010)$ \\
\hline Health & $0.023^{* *}(0.003)$ & $0.019 * *(0.004)$ & $0.027^{* *}(0.005)$ \\
\hline Intercept & $2.096^{* *}(0.191)$ & $1.527^{* *}(0.320)$ & $2.303^{* *}(0.243)$ \\
\hline Adjusted $\mathrm{R}^{2}$ & 0.054 & 0.056 & 0.067 \\
\hline Number of observations & 8440 & 5582 & 2858 \\
\hline
\end{tabular}




\begin{tabular}{|c|c|c|c|}
\hline & All & Men & Women \\
\hline Gender & $0.274^{* *}(0.027)$ & & \\
\hline Employed & $0.385^{* *}(0.034$ & $0.258^{* *}(0.045)$ & $0.557^{\star *}(0.055)$ \\
\hline Years of education & $0.029^{* *}(0.005)$ & $0.013^{*}(0.006)$ & $0.069^{* *}(0.009)$ \\
\hline Log Age squared & $0.042(0.060)$ & $-0.155(0.096)$ & $0.171^{*}(0.081)$ \\
\hline Log Age & $0.222(0.439)$ & $1.611^{*}(0.716)$ & $-0.568(0.584)$ \\
\hline City & $-0.006(0.030)$ & $0.010(0.038)$ & $-0.038(0.052)$ \\
\hline Municipality & $0.002(0.011)$ & $0.000(0.013)$ & $0.002(0.019)$ \\
\hline Years in house & $0.001(0.001)$ & $0.002(0.001)$ & $-0.003(0.002)$ \\
\hline Living together & $0.047(0.033)$ & $0.078(0.045)$ & $-0.041(0.053)$ \\
\hline Child aged $<4$ & $0.031(0.048)$ & $0.077(0.062)$ & $-0.033(0.078)$ \\
\hline Child aged 4 - 12 & $-0.057(0.044)$ & $-0.015(0.056)$ & $-0.133^{*}(0.074)$ \\
\hline Child aged $12-18$ & $0.010(0.049)$ & $0.153^{*}(0.061)$ & $-0.228^{* *}(0.083)$ \\
\hline Child aged $>18$ & $0.009(0.043)$ & $0.045(0.054)$ & $-0.074(0.069)$ \\
\hline Log household income & $0.119^{* *}(0.021)$ & $0.064^{*}(0.025)$ & $0.241^{* *}(0.036)$ \\
\hline Ethnic minority & $-0.090(0.070)$ & $-0.178^{*}(0.089)$ & $0.074(0.112)$ \\
\hline Conservative & $-0.295^{\star \star}(0.025)$ & $-0.313^{* *}(0.030)$ & $-0.228^{* *}(0.044)$ \\
\hline Health & $-0.043^{* *}(0.013)$ & $-0.033^{\star *}(0.016)$ & $-0.060^{* *}(0.021)$ \\
\hline Intercept & $-3.193^{* *}(0.832)$ & $-4.690^{* *}(1.359)$ & $-3.454^{* *}(1.104)$ \\
\hline Pseudo $\mathrm{R}^{2}$ & 0.036 & 0.021 & 0.063 \\
\hline Loglikelihood & -7551.308 & -5005.000 & -2486.106 \\
\hline Number of observations & 11381 & 7380 & 4001 \\
\hline
\end{tabular}




\begin{tabular}{|c|c|c|c|}
\hline & All & Men & Women \\
\hline Gender & $-0.103(0.029)^{* *}$ & & \\
\hline Employed & $-0.040(0.036)$ & $-0.039(0.047)$ & $-0.003(0.059)$ \\
\hline Years of education & $0.014(0.005)$ ** & $0.014(0.006)$ * & $0.008(0.010)$ \\
\hline Log Age squared & $0.248(0.091)$ ** & $0.201(0.098)$ * & $0.547(0.268)$ * \\
\hline Log Age & $-1.573(0.679)$ * & $-1.144(0.729)$ & $-3.937(1.995)$ * \\
\hline City & $0.028(0.031)$ & $0.034(0.039)$ & $0.015(0.053)$ \\
\hline Municipality & $-0.006(0.011)$ & $-0.001(0.014)$ & $-0.019(0.020)$ \\
\hline Years in house & $-0.001(0.001)$ & $0.001(0.001)$ & $-0.005(0.002)$ * \\
\hline Living together & $0.479(0.038)$ ** & $0.515(0.053)$ ** & $0.420(0.058)^{* *}$ \\
\hline Child aged $<4$ & $-0.039(0.050)$ & $-0.060(0.063)$ & $0.003(0.082)$ \\
\hline Child aged 4 - 12 & $-0.113(0.045)$ * & $-0.201(0.057)^{* *}$ & $0.044(0.074)$ \\
\hline Child aged $12-18$ & $-0.064(0.051)$ & $-0.120(0.064)$ & $0.049(0.084)$ \\
\hline Child aged $>18$ & $0.094(0.046)$ * & $0.045(0.059)$ & $0.161(0.075)$ * \\
\hline Log household income & $0.131(0.022) * *$ & $0.140(0.027)$ ** & $0.111(0.037)^{* *}$ \\
\hline Ethnic minority & $-0.012(0.076)$ & $0.016(0.097)$ & $-0.048(0.122)$ \\
\hline Log social network & $0.086(0.028)$ ** & $0.088(0.034)$ * & $0.093(0.048)$ \\
\hline Log social safety net & $0.412(0.056)$ ** & $0.396(0.069) * *$ & $0.443(0.096)$ ** \\
\hline $\begin{array}{l}\text { Conservative } \\
\text { Member of union or }\end{array}$ & $0.077(0.026)$ ** & $0.072(0.032) *$ & $0.090(0.047)$ \\
\hline association & $-0.002(0.026)$ & $-0.041(0.031)$ & $0.081(0.047)$ \\
\hline $\begin{array}{l}\text { Health } \\
\text { Location parameters }\end{array}$ & $0.399(0.014)^{* *}$ & $0.413(0.018)^{* *}$ & $0.375(0.023)$ ** \\
\hline$\alpha 1$ & $-1.333(1.286)$ & $-0.031(1.386)$ & $-6.188(3.720)$ \\
\hline$\alpha 2$ & $-1.110(1.284)$ & $0.115(1.385)$ & $-5.801(3.717)$ \\
\hline$\alpha 3$ & $-0.812(1.283)$ & $0.384(1.384)$ & $-5.264(3.715)$ \\
\hline$\alpha 4$ & $-0.353(1.282)$ & $0.806(1.383)$ & $-4.804(3.715)$ \\
\hline$\alpha 5$ & $0.043(1.282)$ & $1.163(1.383)$ & $-4.230(3.714)$ \\
\hline$\alpha 6$ & $0.617(1.282)$ & $1.743(1.383)$ & $-3.186(3.714)$ \\
\hline$\alpha 7$ & $1.705(1.282)$ & $2.862(1.383)$ & $-1.735(3.714)$ \\
\hline$\alpha 8$ & $3.210(1.282)$ & $4.397(1.384)$ & $-0.815(3.714)$ \\
\hline$\alpha 9$ & $4.060(1.282)$ & $5.219(1.384)$ & \\
\hline Pseudo R2 & 0.069 & 0.071 & 0.067 \\
\hline Loglikelihood & -9354.812 & -6142.714 & -3187.972 \\
\hline Number of observations & 7139 & 4769 & 2370 \\
\hline
\end{tabular}

* significant at $5 \%$ level; ** significant at $1 \%$ level. 


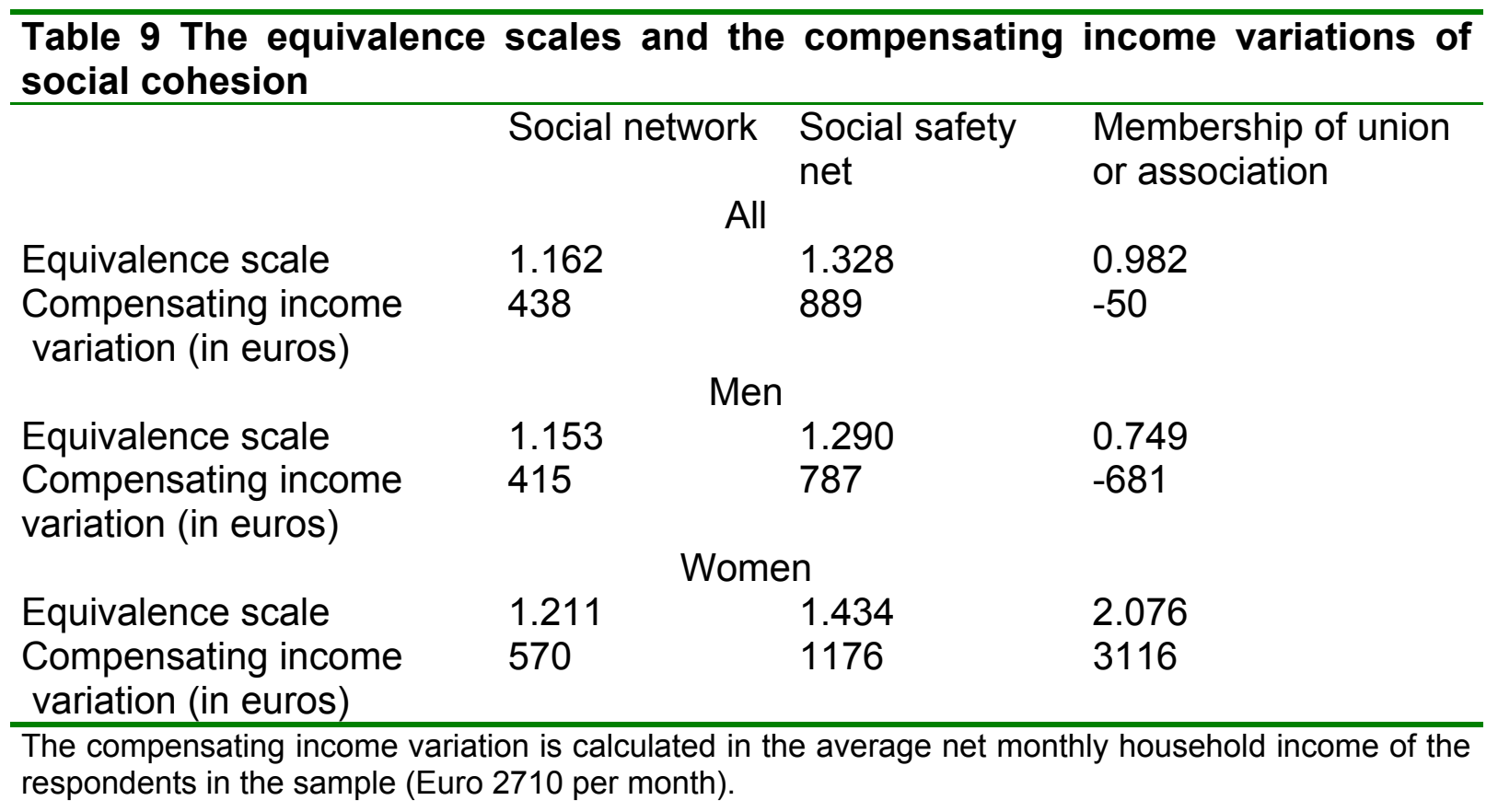

